Special issue of the International Conference on Computational and Experimental Science and Engineering (ICCESEN 2014)

\title{
The Effect of Boron Compound to Cement Hydration and Controllability of this Effect
}

\author{
M. DAVRAZ* \\ Suleyman Demirel University, Natural and Industrial Building Materials Application and Research Center, \\ Isparta, Turkey
}

\begin{abstract}
The use of boron compounds as composites of cementitious, except for the limited usage conditions like setting retarder has not become widespread because of the hardening and the related problems. In this study, the effects of the boron compounds into hydration process of the different cement types and controllability of these effects was investigated. Portland cement, boron modified active belite cement, and calcium aluminate cement were used in the mortar mixtures as binder material. Except for the control mixture, boric acid (BA) was used at the ratios of $0.25-1.00 \%$ of weight of cement in mortar mixtures with Portland cement. Setting times dependent on pH, EC and $T$ changes of fresh mortars were measured. With increasing BA concentration, setting times of the mortars rather increased, $\mathrm{pH}$, electrical conductivity, and $T$ values of the mortars significantly reduced. To suppress the affect of BA on the hydration process, the two various stabilizers were used in the mortars, setting times, pH, electrical conductivity, and $T$ values of these mortars were measured again. As a result, the optimum workability times and the parameters of the hydration reaction taking into account, the most suitable type and usage ratio of stabilizer were determined for mortars with BA.
\end{abstract}

DOI: 10.12693/APhysPolA.128.B-26

PACS: 81.05.Mh

\section{Introduction}

Boron compounds (BC) such as boric acid $\left(\mathrm{B}[\mathrm{OH}]_{3}\right)$ and borates extend the period of cement hydration. Therefore, BCs are used in concrete as an efficient set retarding admixture, such as hydroxylated carboxylic acid, lignins, sugar and some phosphate compounds. Borates have been used regularly in oil-well cementing operations both as a conventional retarder and also an auxiliary admixture for viscosity at high temperatures [1]. Furthermore, radioactive wastes of nuclear power plants is mixed with high borate concentration solutions and then this mixture is solidified using cement to store in underground. However, during the hardening process, major strength problems have not been resolved yet. Excluding these two specific conditions of use, the use of $\mathrm{BC}$ with inorganic binders could be become widespread so far because of hardening and the related strength problems.

In recent years, many researches have been carried out for the usability of boron wastes on cement production. Kula et al. have stated that the use of tincal ore waste also gives rise to an improvement in the properties of the Portland cement (PC) at 1\% replacement level. Although it retards setting time (ST), it gives an opportunity for use as a cement replacement material up to $5 \mathrm{wt} \%$ of the cement [2].

According to Targan et al., the compressive strength of concrete specimens made by cement with grinding the $81-96 \%$ Portland clinker, $4 \%$ colemanite waste and $5-15 \%$ natural pozzolan materials at 90 days of curing

\footnotetext{
*e-mail: metindavraz @sdu.edu.tr
}

performs $90 \%$ of control concrete specimens [3]. In 2006 year, GOLTAS Cement Factory in Turkey has produced boron modified active belite cement (BAB) with using colemanite ore. In researches on this cement type, it is stated that this product could be successfully used specially in dam concretes due to its very low hydration temperature (HT) with no alite phase.

In addition, the final compressive strength of concrete made by $\mathrm{BAB}$ cement is much higher than that of concrete's made by PC [4]. In appropriate concentrations, properties such as shrinkage and fire resistibility of concrete and other cementitious composites including BCs may be improved. Furthermore, these products may also gain new features such as radiation impermeability and antibacteriality. In some researches, studied on this subject, Volkman et al. (1992) have stated that as adding the BCs to concrete, they absorb the neutrons and low energy gamma rays spread. Therefore, there could be supplied an effective radiation protection.

However, adding boron compound to concrete mix seriously retards the ST and decreases the concrete strength [5].

On the other hand, Demir et al. [6] have prepared the concrete specimens including borogypsum and colemanite concentrator wastes. They tested the differences in gamma rays passing energies for normal and boron waste (BW) additive concretes specimens. They observed that concrete specimens including BW supply an effective protection against radioactive radiations.

BOREN stated that BAB cement has more than $20 \%$ of a neutron absorbing capacity comparing to PC [7]. The improvements and additional features provided $\mathrm{BCs}$ to concrete and cementitious composites are very closely relevant to $\mathrm{B}_{2} \mathrm{O}_{3}$ concentrations of using BCs. 
Furthermore, increasing the $\mathrm{B}_{2} \mathrm{O}_{3}$ concentration slows down the cement hydration and even stops it. Extending the ST depending on that situation is known and an intensively research phenomenon.

In Taylor paper [8] borates are mentioned very briefly as being compounds that generally retard cement hydration, possibly by a precipitation mechanism.

In Conner work [9] borates are listed as short-term setting retarders that disrupt the cement matrix.

Jeffrey et al. [10] found that it was difficult to stabilize any liquid BW waste having a concentration of dissolved boron of more than $12 \%$ using cement and extra lime for $\mathrm{pH}$ control.

As adding $\mathrm{BC}$ into mortar mixture, boron trioxide $\left(\mathrm{B}_{2} \mathrm{O}_{3}\right)$ concentration is one of the most important factors affecting the quality of cementitious composites (fire resistant, neutron shield etc.). In priority, beneficial $\mathrm{B}_{2} \mathrm{O}_{3}$ concentration should be determined depending on the aim. The concentration depends on the $\mathrm{B}_{2} \mathrm{O}_{3} \%$ of compound including. As the $\mathrm{B}_{2} \mathrm{O}_{3}$ concentration decreases $(<0.20 \%)$, the hardening retard and the strength decreases will improve linearly as well. However, physical and chemical benefits of $\mathrm{B}_{2} \mathrm{O}_{3}$ to cement composite will decrease. Forming calcium diborate $\left(\mathrm{CBH}_{6}\right)$ barrier layers on grain surfaces should be delayed to reach to optimum ST and the strength value in relevant $\mathrm{B}_{2} \mathrm{O}_{3}$ concentration. Thus, effects on cement hydration of both the direct and indirect using method of $\mathrm{B}_{2} \mathrm{O}_{3}$ were researched in this study. For this purpose, the effect of combined use of $\mathrm{B}[\mathrm{OH}]_{3}$ as a $\mathrm{B}_{2} \mathrm{O}_{3}$ source and accelerator additive materials on mortar set time and cement hydration was also investigated in this study.

\section{Material and methods}

BA obtained from Eti Mine as a source of $\mathrm{B}_{2} \mathrm{O}_{3}, \mathrm{PC}$ and $\mathrm{BAB}$ obtained from GOLTAS and calcium aluminate cement (CAC) obtained from CIMSA were used in this study. Also accelerator additive materials such as calcium chloride ( $\mathrm{CC}$ ), sodium aluminate (SA) were added in the mortar mixtures in order to suppress the retarding affect of BA to cement hydration. The dosages of cement used in all specimens are equal. Physical and chemical properties of $\mathrm{PC}, \mathrm{BAB}$ and $\mathrm{CAC}$ cements used as a binder were given in Table $\mathrm{I}$.

TABLE I

Physical and chemical properties of cements used as a binder [11, 12].

\begin{tabular}{|c|c|c|c|c|c|c|c|}
\hline \multicolumn{4}{|c|}{ Chemical prop. of clinkers } & & \multicolumn{3}{|c|}{ Physical prop. of cements } \\
\hline \multicolumn{4}{|c|}{ Components [\%] } & & $\mathrm{OPC}$ & $\mathrm{BAB}$ & $\mathrm{CAC}$ \\
\hline $\mathrm{SiO}_{2}$ & 20.52 & 20.37 & 2.20 & volumetric expansion $[\mathrm{mm}]$ & 1 & 0 & 0 \\
\hline $\mathrm{Al}_{2} \mathrm{O}_{3}$ & 4.00 & 4.45 & 40.70 & fineness $[90 \mu \mathrm{m}]$ & 0.1 & 0.1 & 6.5 \\
\hline $\mathrm{Fe}_{2} \mathrm{O}_{3}$ & 3.45 & 3.27 & 17.00 & slightness $[200 \mu \mathrm{m}]$ & 1.1 & 1.8 & 1.2 \\
\hline $\mathrm{CaO}$ & 64.28 & 58.19 & 38.20 & specific surface area $\left[\mathrm{cm}^{2} / \mathrm{g}\right]$ & 3340 & 3560 & 3540 \\
\hline $\mathrm{MgO}$ & 1.63 & 4.70 & 0.80 & initial setting time [min] & 185 & 220 & 245 \\
\hline $\mathrm{SO}_{3}$ & 2.53 & 3.08 & 0.02 & final setting time [min] & 240 & 265 & 265 \\
\hline $\mathrm{Na}_{2} \mathrm{O}+\mathrm{K}_{2} \mathrm{O}$ & 1.35 & 1.50 & 0.07 & specific gravity $\left[\mathrm{g} / \mathrm{cm}^{3}\right]$ & 3.12 & 2.98 & 3.29 \\
\hline $\mathrm{B}_{2} \mathrm{O}_{3}$ & 0.00 & 1.12 & 0.00 & flexural strength [MPa, at 2 days] & 4.5 & 2.5 & $6.0^{a}$ \\
\hline $\mathrm{CaO}$ (free) & 1.81 & 0.63 & - & flexural strength [MPa, at 7 days] & 5.8 & 4.1 & $7.5^{b}$ \\
\hline L.O.I. & 2.72 & 4.02 & 0.30 & flexural strength [MPa, at 2 days] & 7.2 & 6.0 & $9.5^{c}$ \\
\hline \multicolumn{4}{|c|}{ Clinker phases [\%] } & compressive strength [MPa, at 2 days] & 11.7 & 11.7 & $55.2^{d}$ \\
\hline $\mathrm{C}_{3} \mathrm{~S}$ & - & \multicolumn{2}{|c|}{56.66} & compressive strength [MPa, at 7 days] & 39.3 & 23.2 & 81.6 \\
\hline $\mathrm{C}_{2} \mathrm{~S}$ & 66.23 & \multicolumn{2}{|c|}{17.65} & compressive strength [MPa, at 28 days] & 51.0 & 38.6 & - \\
\hline $\mathrm{C}_{3} \mathrm{~A}$ & 7.86 & \multicolumn{2}{|c|}{6.33} & \multicolumn{4}{|c|}{ Other prop. of cements } \\
\hline $\mathrm{C}_{4} \mathrm{AF}$ & 14.01 & \multicolumn{2}{|c|}{12.03} & $\mathrm{Cl}^{-}$ & 0.000 & 0.006 & 0.000 \\
\hline
\end{tabular}

${ }^{a} 6 \mathrm{~h},{ }^{b} 24 \mathrm{~h},{ }^{c} 6 \mathrm{~h},{ }^{d} 24 \mathrm{~h}$

In cement-compounds in order to reach the optimal ST and strength value in an appropriate concentration of the $\mathrm{B}_{2} \mathrm{O}_{3}$ it is needed to prevent the formation of barrier layers on the surface of cement grains or at least delay this. In this study at first chemical additive types that can prevent the retardation of ST in different cementitious compounds having $\mathrm{B}_{2} \mathrm{O}_{3}$ concentration and with the aim of determining usage ratios, 35 different mortar specimens were prepared as two for each (Table II). Each mortar specimen prepared, primarily initial setting times (IST) and final setting times (FST) were measured with automatic Vicat apparatus as appropriate to TS EN 196-3 standards [13]. 
TABLE II

The components of mortar specimens.

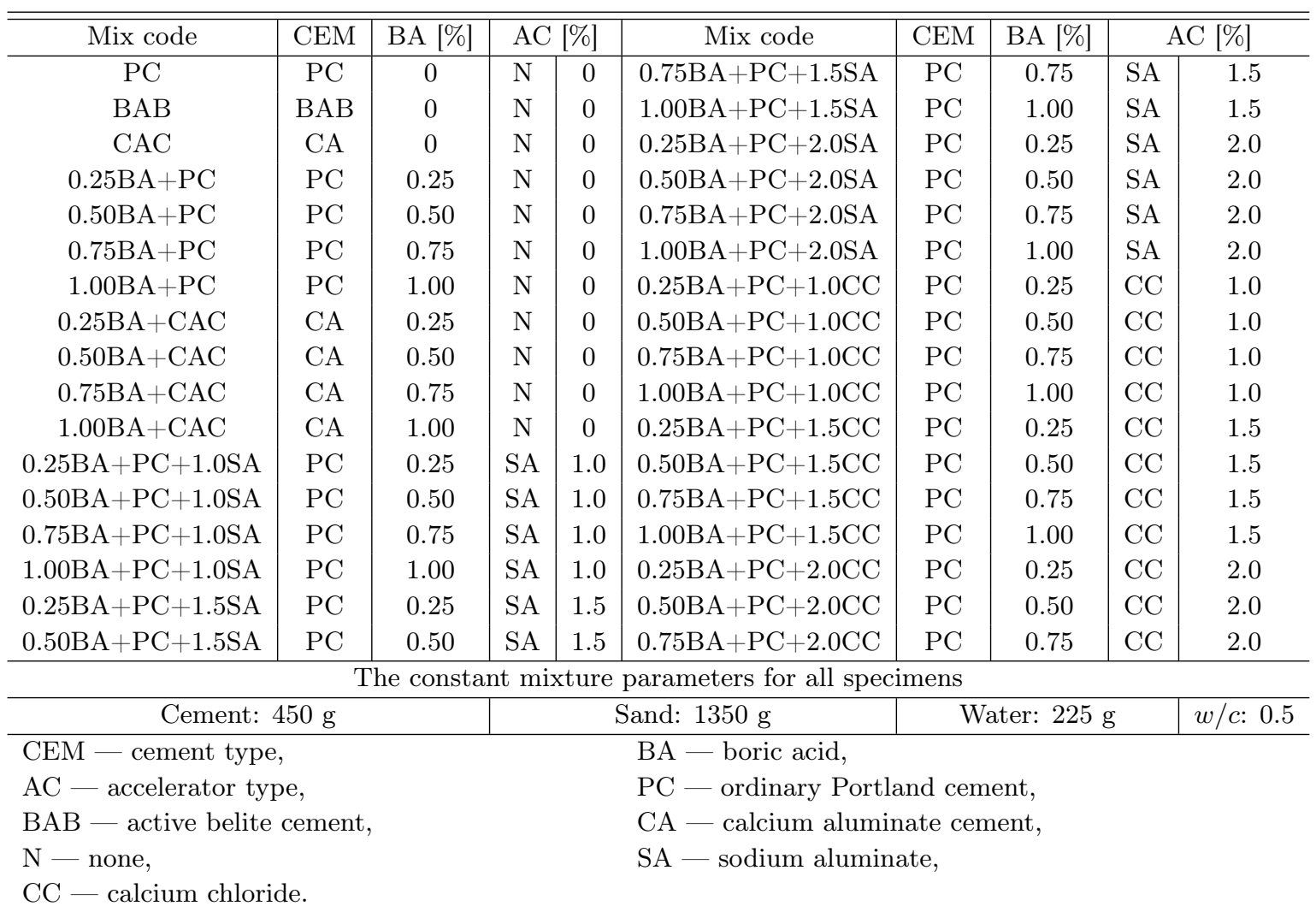

$\mathrm{pH}$ value and electrical conductivity (EC) of pore water are related to total anion and cation quantity in the process of hydration of cement compounds. As the amount of water-soluble salts increases, EC increases. Basic components forming $\mathrm{PC}$ such as tricalcium silicate $\left(\mathrm{C}_{3} \mathrm{~S}\right)$, dicalcium silicate $\left(\mathrm{C}_{2} \mathrm{~S}\right)$, tricalcium aluminate $\left(\mathrm{C}_{3} \mathrm{~A}\right)$ and tetracalcium aluminoferrite $\left(\mathrm{C}_{4} \mathrm{AF}\right)$ react with water and form the hydration products. During hydration, amounts of cation such as $\mathrm{Ca}^{++}, \mathrm{Mg}^{++}, \mathrm{Na}^{+}$, $\mathrm{K}^{+}$and $(\mathrm{OH})^{-}$anion increase depending upon cement type, fineness, $\mathrm{pH}$ value of environment and temperature $(T)$ of the environment in pore water compared to mixing water. So $\mathrm{pH}, T$ and EC values measured in cement paste increases quickly with the contact of cement with water. However $\mathrm{pH}, \mathrm{T}$ and $\mathrm{EC}$ values of the environment are expected to decrease in case of presence of substances which can be water-soluble and form compound with anions or cations in the environment. Taking into account above consideration, firstly, mortars were prepared by $\mathrm{CAC}$, the $\mathrm{BAB}$ and $\mathrm{AC}$ added $\mathrm{PC}$, then the affect of $\mathrm{B}_{2} \mathrm{O}_{3}$ concentration on $T, \mathrm{pH}$ and $\mathrm{EC}$ values of these specimens were analyzed in detail.

\section{Result and discussion}

When $2 \mathrm{~mol} \mathrm{~B}[\mathrm{OH}]_{3}$ are heated about $600^{\circ} \mathrm{C}$ $\left(2 \mathrm{~B}[\mathrm{OH}]_{3}+\right.$ heat $\left.\rightarrow \mathrm{B}_{2} \mathrm{O}_{3}+3 \mathrm{H}_{2} \mathrm{O}\right)$ it forms 1 mol $\mathrm{B}_{2} \mathrm{O}_{3}$ and $3 \mathrm{~mol}$ water. When $1 \mathrm{~g} \mathrm{~B}[\mathrm{OH}]_{3}$ is heated, approximately $0.577 \mathrm{~g} \mathrm{~B}_{2} \mathrm{O}_{3}$ is obtained. $\mathrm{B}_{2} \mathrm{O}_{3}$ ratios corresponding stoichiometrically to 4 different ratios of $\mathrm{B}[\mathrm{OH}]_{3}$ used in cement specimens are calculated with the relation given in Eq. (1):

$$
M_{\mathrm{B} 2 \mathrm{O} 3}=c \times 0.02 \times 0.577 \text {. }
$$

Here $M_{\mathrm{B} 2 \mathrm{O} 3}$ is the amount of $\mathrm{B}_{2} \mathrm{O}_{3}$ included in mortar mixture and $c$ is cement dosage. The $\mathrm{B}_{2} \mathrm{O}_{3}$ ratio of BAB cement is calculated as the $1.12 \%$ of cement weight. Changes in IST and FST of cement specimens according to $\mathrm{B}_{2} \mathrm{O}_{3} / c$ ratio are given in Figs. $1-3$. According to this:

- When compared to the control mortars with PC, the more $\mathrm{B}_{2} \mathrm{O}_{3} / c$ ratio increases, the more IST of the mortar with PC increases significantly. The IST and FST of mortars at ratio of $\mathrm{B}_{2} \mathrm{O}_{3} / c>$ $0.06 \%$ exceeded the values of $\mathrm{BAB}$ cement. When compared to control mortars with $\mathrm{PC}$ and $\mathrm{BAB}$, the IST and FST of control mortars with CAC are much longer. However CAC specimens including $\mathrm{BA}$ at $\mathrm{B}_{2} \mathrm{O}_{3} / c$ ratio of $0.17-0.18$, this time reaches maximum, but it decreases at the ratio of $\mathrm{B}_{2} \mathrm{O}_{3} / c>0.2$.

- $\mathrm{ST}$ of the mortar including $1 \% \mathrm{SA}$ and $\mathrm{BA}$ is closer to the PC mortar, but it is shorter than the $\mathrm{BAB}$ mortar. $\mathrm{SA}$ ratio increases, IST and FST 
decrease for all $\mathrm{B}_{2} \mathrm{O}_{3} / c$ ratios. But this decrease of the ST enables workability. This situation shows difference in the PC mortar which was added CC. Both $\mathrm{CC}$ and $\mathrm{B}_{2} \mathrm{O}_{3} / c$ ratios significantly affect STs. The IST and FST in the specimens added $1 \% \mathrm{CC}$ increase up to the ratio of $\mathrm{B}_{2} \mathrm{O}_{3} / c<0.07$. Even in these ratios STs of BAB mortar are exceeded. On the contrary, the STs of mortars prominently reduced at $\mathrm{B}_{2} \mathrm{O}_{3} / c>0.07$ the ratios. The STs reduced rapidly on higher $\mathrm{CC}$ ratios. However, the workability gets harder at $\mathrm{B}_{2} \mathrm{O}_{3} / c>0.17$ for the $1.5 \% \mathrm{CC}$ ratio and $\mathrm{B}_{2} \mathrm{O}_{3} / c>0.1$ for the $2.0 \%$ CC ratio.

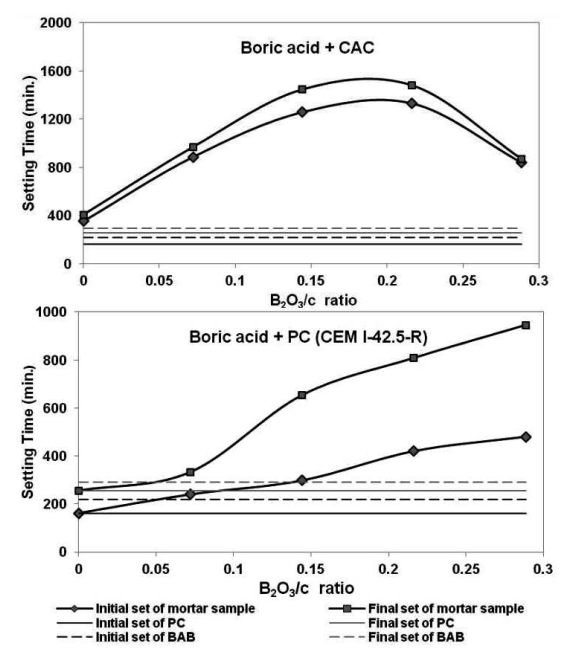

Fig. 1. Changes of IST and FST of PC and CAC mortar including $\mathrm{BA}$ according to $\mathrm{B}_{2} \mathrm{O}_{3} / c$ ratio.
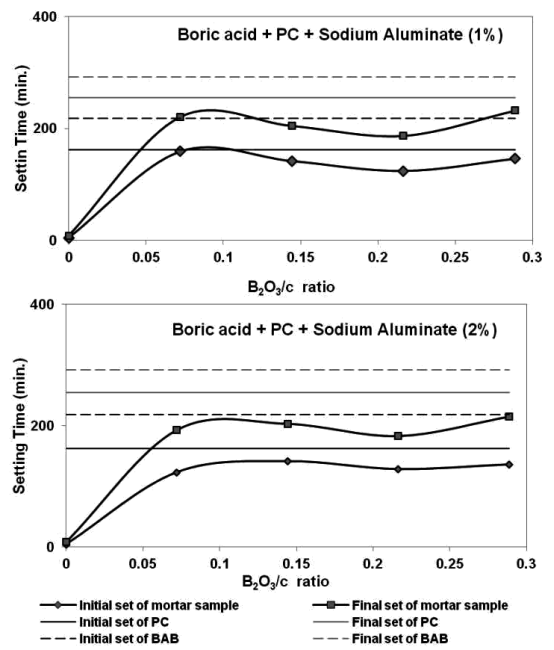

Fig. 2. Changes of IST and FST of PC mortar added $1 \%$ and $2.0 \% \mathrm{SA}$ and $\mathrm{BA}$ depending upon $\mathrm{B}_{2} \mathrm{O}_{3} / c$ ratio.

Besides $T$-pH-EC values depending on the time of mortars are measured with $\mathrm{pH}-\mathrm{EC}$ meter device and the obtained findings were given in Figs. 4-12. According to graphics, the effect of BA on HT changes in the mortar specimens with chemical additive or not were determined as follows.
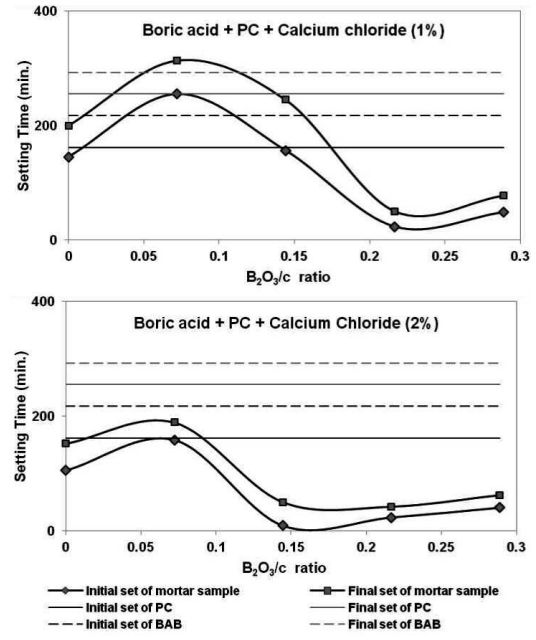

Fig. 3. Changes of IST and FST of PC mortar added $1 \%$ and $2.0 \% \mathrm{CC}$ and $\mathrm{BA}$ depending upon $\mathrm{B}_{2} \mathrm{O}_{3} / c$ ratio.
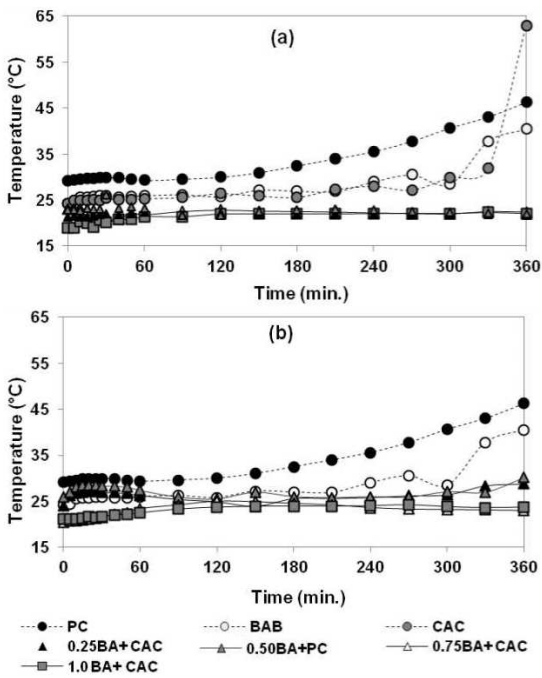

Fig. 4. Time-dependent $T$ changes of the mortar specimens of pure CAC, CAC (a) and PC (b) including different ratios of $\mathrm{BA}$ and also control (pure $\mathrm{PC}$ and $\mathrm{BAB}$ ).

While $T$ of components were $\approx 20^{\circ} \mathrm{C}$ prior to the mix, when the PC from control specimens contacted with water, the average $T$ of mixture increased to $29^{\circ} \mathrm{C}$ and after $6 \mathrm{~h}$ it reached $46^{\circ} \mathrm{C}$. The $T$ of BAB mortar which is another control specimen increased to $\approx 24^{\circ} \mathrm{C}$ immediately after contacting water and after $6 \mathrm{~h}$ it reached approximately $40^{\circ} \mathrm{C}$. On the contrary, while the $T$ of CAC mortar was $\approx 24^{\circ} \mathrm{C}$ after contacting water, after $6 \mathrm{~h}$ it exceeded approximately $63^{\circ} \mathrm{C}$. The $\mathrm{HT}$ of CAC specimens which was added $\mathrm{BA}$ at $0.25-0.50-0.75$ and $1.0 \%$ ratios by weight of cement remained about $\approx 22^{\circ} \mathrm{C}$. This situation shows that the hydration of $\mathrm{CAC}$ cement was completely stopped by the ratio of $1 \% \mathrm{BA}$ at the $6 \mathrm{~h}$ period. The HT of PC mortars including $0.25-0.5 \%$ BA close to BAB specimens. On the other hand, the $T$ of $\mathrm{PC}$ specimens with $0.75-1 \% \mathrm{BA}$ were around $\approx 24^{\circ} \mathrm{C}$ during the same period. It also shows that $\mathrm{BA}$ significantly retard the hydration of PC, though not as much as CAC (Fig. 4). 


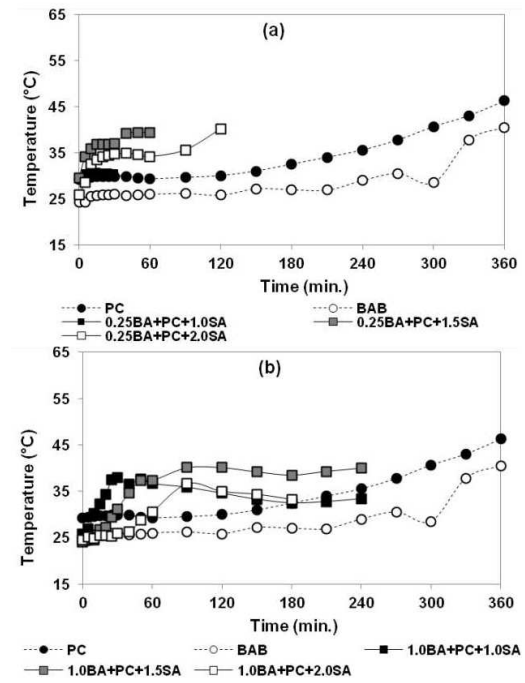

Fig. 5. Time-dependent $T$ changes of PC mortar specimens which were added $0.25 \% \mathrm{BA}(\mathrm{a})$ and $1.0 \% \mathrm{BA}(\mathrm{b})$ as well as at the different rates of SA and also control mortars.
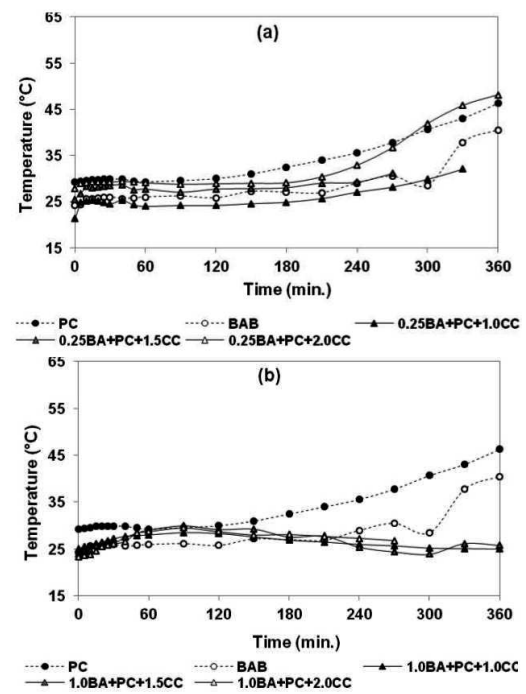

Fig. 6. Time-dependent $T$ changes of PC mortar specimens which were added $0.25 \% \mathrm{BA}$ (a) and $1.0 \% \mathrm{BA}(\mathrm{b})$ as well as at the different rates of $\mathrm{CC}$ and also control mortars.

The $T$ changes related to time of specimens added SA and BA free could not be measured because of very rapid setting of specimens $(<10 \mathrm{~min})$. On the contrary, the HTs of specimens with SA and $0.25 \%$ BA increased as related to increase of SA ratio (for $1.5-2 \% \mathrm{SA}$ ) and it reached approximately $40^{\circ} \mathrm{C}$ after $6 \mathrm{~h}$. While the $\mathrm{HT}$ of mortars with SA did not change too much together with increases of BA ratio, the STs of specimens extended. In addition, the $\mathrm{HT}$ of mortar with $1 \% \mathrm{BA}$ decreased to the level of PC specimens, while the HT of mortars including BA at rates of $0.25-0.50-0.75 \%$ were too much from the values of PC specimens (Fig. 5). The HTs of mortars with 1-1.5\% CC and not including BA generally were between $\mathrm{PC}$ and $\mathrm{BAB}$ (control) specimens and the HTs of specimens with $2 \% \mathrm{CC}$ reached $\approx 57^{\circ} \mathrm{C}$ after $6 \mathrm{~h}$. While the HTs of specimens including $0.25 \% \mathrm{BA}$ and $2 \% \mathrm{CC}$ similarly exceeded $\approx 48^{\circ} \mathrm{C}$ after $6 \mathrm{~h}$, the HTs of other specimens remained below the values of $\mathrm{BAB}$ specimens (Fig. 6).

The effect of $\mathrm{BA}$ to $\mathrm{pH}$ changes of porous water in mortar specimens with or without accelerator additive was explained in below according to Figs. 7, 8 and 9:

- At the beginning of hydration, the concentrations of free $\mathrm{Ca}^{++}, \mathrm{Mg}^{++}, \mathrm{Na}^{+}$and $\mathrm{K}^{+}$cations and $(\mathrm{OH})^{-}$anions dissolved from the cement compounds are high. The cement paste formed from hydrate gels begins to solidify, the concentration of alkaline ions in porous water slightly reduces. $\mathrm{pH}$ value of cement paste is an important indicator in terms of speed and continuity of hydration, even if not about strength.

- While $\mathrm{pH}$ value of control PC specimen was about 13.0 at the beginning, it regressed to 12.4 after $6 \mathrm{~h}$. $\mathrm{pH}$ value of $\mathrm{BAB}$ specimens was also about 13.0 at the beginning, it decreased gradually until value of 12 in $300 \mathrm{~min}$, and then it reached rapidly value of 12.8 after $6 \mathrm{~h}$. This situation can be correlated to the forming $\mathrm{CBH}_{6}$ compound as dissolving of $\mathrm{BCs}$ in chemical structure of $\mathrm{BAB}$ cement $(\approx 1.12 \%$ $\left.\mathrm{B}_{2} \mathrm{O}_{3}\right)$ in alkaline medium, it precipitates on the surfaces of cement particles and $\mathrm{CBH}_{6}$ compound dissolution due to lack of enough alkaline ions in the pore water, so beginning of hydration again. While $\mathrm{pH}$ value of $\mathrm{CAC}$ specimen without $\mathrm{BA}$ was value of 11.8 at the beginning, it decreased to value of 9.4 at the end of $330 \mathrm{~min}$ and at the end of $6 \mathrm{~h}$ it reached to value of 11.4 again. These values are significantly lower both from the values of the PC and $\mathrm{BAB}$ specimens. This situation is specific to the CAC cement and may be caused by the presence of about $\frac{1}{2}$ ratio of $\mathrm{CaO}$ in the chemical structure of $\mathrm{CAC}$ clinker compared to the $\mathrm{PC}$ clinker. $\mathrm{pH}$ value in $\mathrm{CAC}$ specimens with $\mathrm{BA}$ decreased approximately to values of $8-9$ depending upon the increasing $\mathrm{BA}$ ratio. This situation indicates that $\mathrm{BCs}$ retard to the $\mathrm{ST}$ of $\mathrm{CAC}$ cement is much longer compared to the PC. In the PC specimens including $\mathrm{BA}, \mathrm{pH}$ values decreased at a $270 \mathrm{~min}$ period depending upon the BA ratio compared to the control PC specimens and it reached to the same ratio again at the end of $6 \mathrm{~h}$ period. However the $\mathrm{pH}$ values of all specimens in this group were much higher than $\mathrm{BAB}$ specimens at the end of $330 \mathrm{~min}$ period (Fig. 7).

- The $\mathrm{pH}$ values in all of specimens with $\mathrm{SA}$ and $\mathrm{BA}$ at $0.25 \%$ ratio were lower than both the $\mathrm{PC}$ and $\mathrm{BAB}$ specimens. However this situation may be related to the very rapid setting. The more $\mathrm{SA}$ ratio increased, the more $\mathrm{pH}$ value decreased to a value of about 10 depending on the speed 


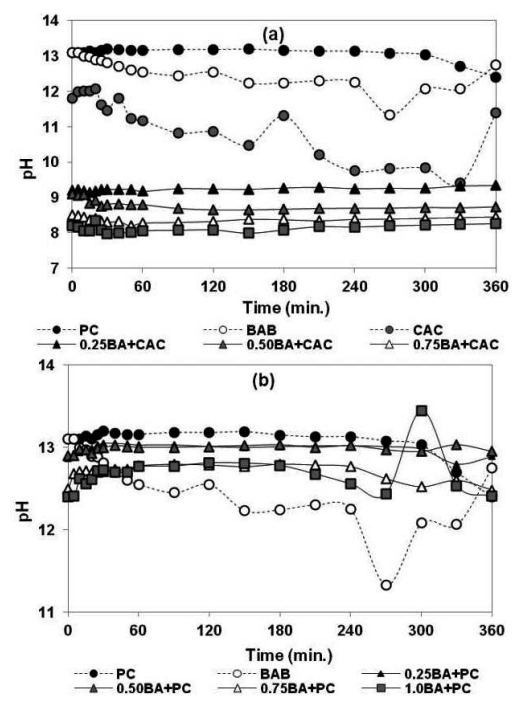

Fig. 7. Time-dependent $\mathrm{pH}$ changes of pure CAC, different ratios of $\mathrm{BA}$ including $\mathrm{CAC}(\mathrm{a})$ and $\mathrm{PC}(\mathrm{b})$ and control mortar mixtures.
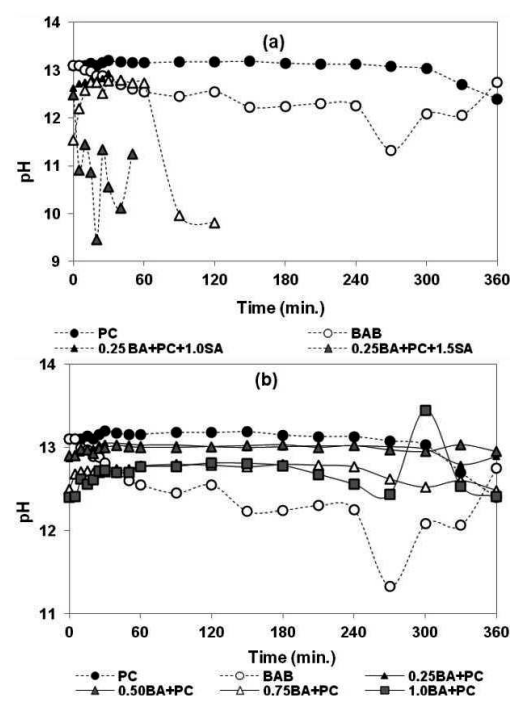

Fig. 8. Time-dependent $\mathrm{pH}$ changes of $\mathrm{PC}$ mortar specimens which were added $0.25 \% \mathrm{BA}(\mathrm{a})$ and $1.0 \% \mathrm{BA}(\mathrm{b})$ as well as at the different rates of SA and also control mortars.

of cement paste setting. In the specimens with $\mathrm{SA}$ and $\mathrm{BA}$ at $0.50 \%$, while the $\mathrm{pH}$ values were the range of $\mathrm{pH}$ values of $\mathrm{PC}$ and $\mathrm{BAB}$ specimens for the $30-120$ min period, it decreased to a value of 9.4 depending on solidifying in about $150 \mathrm{~min}$. While the $\mathrm{pH}$ values of specimens with $1-2 \% \mathrm{SA}$ and $0.75 \% \mathrm{BA}$ were the range of $\mathrm{pH}$ values of $\mathrm{PC}$ and $\mathrm{BAB}$ specimens for the $30-180 \mathrm{~min}$ period, the $\mathrm{pH}$ value of the specimen with $2 \% \mathrm{SA}$ fluctuated in the range of $12.8-10.5$ in $60-180$ min period and then the specimen solidified the $\mathrm{pH}$ value of 10.8 . Initially, while the $\mathrm{pH}$ values of specimens with $\mathrm{SA}$ and $1 \% \mathrm{BA}$ had a $\mathrm{pH}$ value of about 11.5 , it reached to the value of $12.6-13.0$ in the $30-240$ min (Fig. 8).

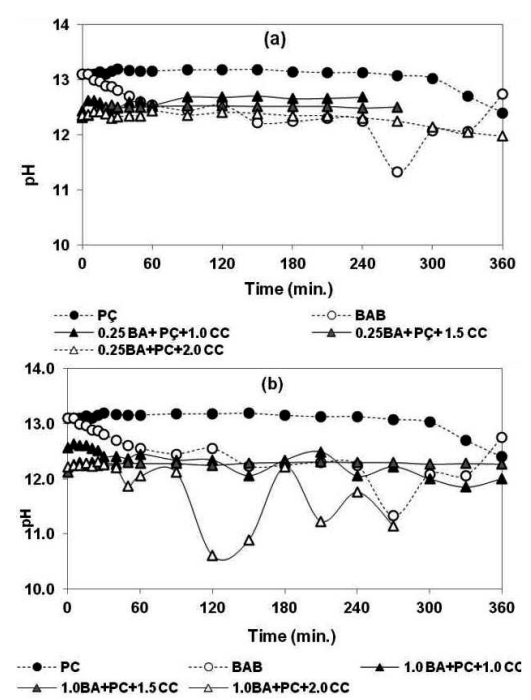

Fig. 9. Time-dependent $\mathrm{pH}$ changes of $\mathrm{PC}$ mortar specimens which were added $0.25 \% \mathrm{BA}$ (a) and $1.0 \% \mathrm{BA}(\mathrm{b})$ as well as at the different rates of $\mathrm{CC}$ and also control mortars.

- The $\mathrm{pH}$ values of specimens with $\mathrm{CC}$ and without $\mathrm{BA}$ were the range of $\mathrm{pH}$ values of $\mathrm{PC}$ and $\mathrm{BAB}$ specimens, and the more $\mathrm{CC}$ ratio increased the more $\mathrm{pH}$ value of these specimens approached to $\mathrm{BAB}$ specimens. A similar situation was true for the specimens with $\mathrm{CC}$ and $0.25-0.50 \% \mathrm{BA}$, as the $\mathrm{BA}$ ratio increased the ST gets longer. The specimen with $0.75 \mathrm{BA}$ and $1.5 \% \mathrm{CC}$ did not comply with this situation. In this specimen, the fluctuation of $\mathrm{pH}$ values between 12.4 and 10.1 was a clear indicator of the continued intermittent of hydration. In the $6 \mathrm{~h}$ period, while the $\mathrm{pH}$ values of specimens with $1 \% \mathrm{BA}$ and $1.0-1.5 \% \mathrm{CC}$ were closer to $\mathrm{BAB}$, the $\mathrm{pH}$ value of specimens with $2 \% \mathrm{CC}$ varies between 10.6 and 12.3 , and the specimen solidified in the end of $270 \mathrm{~min}$ (Fig. 9).

By analyzing Figs. 10, 11, and 12, the effect of BA to the EC changes in pore water of specimens with or without chemical additive was explained below.

- At the beginning of hydration, while the $\mathrm{EC}$ value of control PC specimen was $18.7 \times 10^{3} \mathrm{mS} / \mathrm{cm}$, it reached maximal value $\left(26.3 \times 10^{3} \mathrm{mS} / \mathrm{cm}\right)$ in about $270 \mathrm{~min}$. EC value rapidly increased and reached $14.5 \times 10^{3} \mathrm{mS} / \mathrm{cm}$ at $150-180 \mathrm{~min}$ period. It nearly showed a linear decrease and regressed to $10.3 \times 10^{3} \mathrm{mS} / \mathrm{cm}$ at $180-330 \mathrm{~min}$ period and then reached to $17.1 \times 10^{3} \mathrm{mS} / \mathrm{cm}$ at $330-360$ min period. At the same time, this period of time is the FST for PC cement. EC value decreased to $4.4 \times 10^{3} \mathrm{mS} / \mathrm{cm}$ between 270-360 min. In term of $\mathrm{EC}$ value, $\mathrm{BAB}$ control specimen was different from the PC-control specimen. At the beginning of hydration, while the EC value was $8.6 \times 10^{3} \mathrm{mS} / \mathrm{cm}$, this value reached the value of $9.6 \times 10^{3} \mathrm{mS} / \mathrm{cm}$ in the first $10 \mathrm{~min}$ and then it decreased to a value of $3.0 \times 10^{3} \mathrm{mS} / \mathrm{cm}$ 


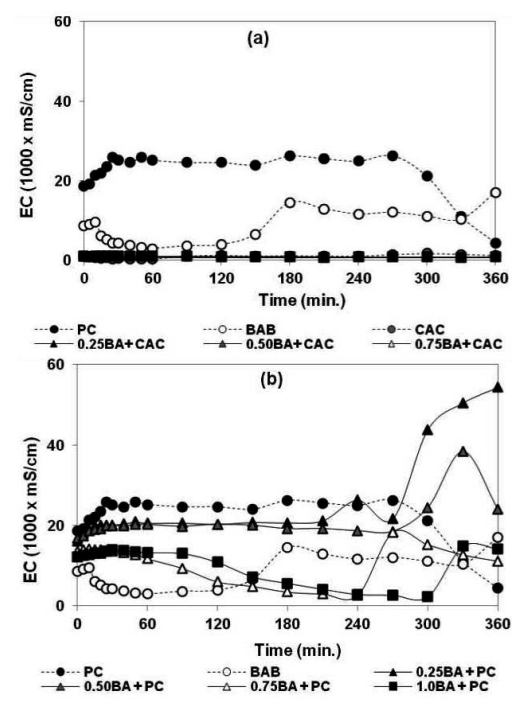

Fig. 10. Time-dependent EC changes of additive free and different ratios of $\mathrm{BA}$ including $\mathrm{CAC}(\mathrm{a})$ and $\mathrm{PC}(\mathrm{b})$ and control mortar mixtures.
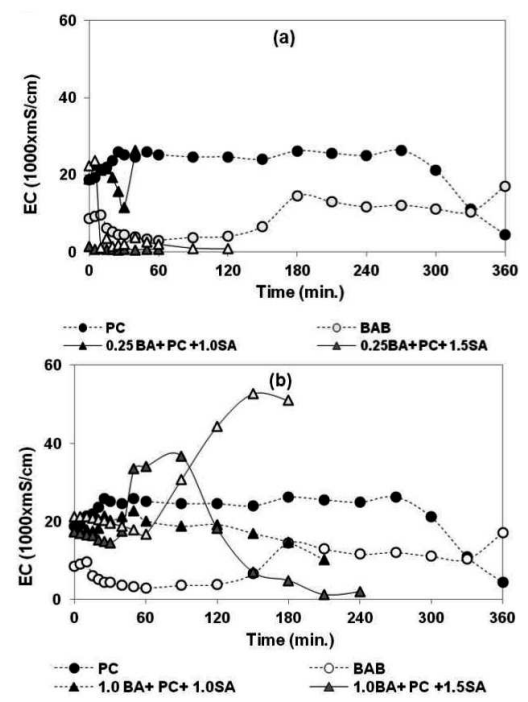

Fig. 11. Time-dependent EC changes of $0.25 \%$ (a) and $1.0 \%$ (b) ratios of $\mathrm{BA}$, different ratios of $\mathrm{SA}$ included PC and control mortar mixtures.

in the next $40 \mathrm{~min}$. In this period, it is thought that $\mathrm{B}[\mathrm{OH}]_{4}$ dissolved in pore water reacted with anions and cations and formed $\mathrm{CBH}_{6}$ (or $\mathrm{N}_{2} \mathrm{BH}_{6}$ and $\mathrm{K}_{2} \mathrm{BH}_{6}$ ) then precipitated on cement particles and retarded hydration. In 150-180 min period, EC values increased rapidly and reached the value of $14.5 \times 10^{3} \mathrm{mS} / \mathrm{cm}$. In 180-330 min period, it showed a linear decrease and regressed to the value of $10.3 \times 10^{3} \mathrm{mS} / \mathrm{cm}$. Then it reached a relatively high value as $17.1 \times 10^{3} \mathrm{mS} / \mathrm{cm}$ in $150-180 \mathrm{~min}$ period. Reducing of the EC values at longer period shows that the formation of $\mathrm{CBH}_{6}$ compounds and these formations covered on the cement particles in a long time. On the contrary, the rapid increase of $\mathrm{EC}$ value in a short time indicated that $\mathrm{CBH}_{6}$ dissolves rapidly as related to the excessive decrease of alkalinity in medium. Precipitation and dissolution cycles continue during hydration period until consuming of ions in the medium (Fig. 10).

- In PC specimen with $\mathrm{BA}$, the more increasing $\mathrm{BA}$ ratio, the more decreasing $\mathrm{EC}$ values. In the specimens with $0.25 \% \mathrm{BA}$, while $\mathrm{EC}$ values were $\approx 20 \times 10^{3} \mathrm{mS} / \mathrm{cm}$ at $40 \mathrm{~min}$, it rapidly reached to $54.4 \times 10^{3} \mathrm{mS} / \mathrm{cm}$ in next period. For the specimens with $0.5 \% \mathrm{BA}$, firstly the $\mathrm{EC}$ value reached $38.5 \times 10^{3} \mathrm{mS} / \mathrm{cm}$ in end of the $330 \mathrm{~min}$ and it regressed to $24 \times 10^{3} \mathrm{mS} / \mathrm{cm}$ between 330 and $360 \mathrm{~min}$. The EC values of specimens with $0.75 \%$ and $1.0 \%$ ratio $\mathrm{BA}$ represent fluctuations such as $13-2.7-18-11.2 \times 10^{3} \mathrm{mS} / \mathrm{cm}$ and $12.1-$ 14-2.3-14.9 × $10^{3} \mathrm{mS} / \mathrm{cm}$, respectively. This situation clearly shows precipitation and dissolution cycles of borate compounds. The EC values of CAC specimens with $\mathrm{BA}$ and without $\mathrm{BA}$ are very low. The $\mathrm{EC}$ values of fresh specimens with $0.25 \% \mathrm{BA}$ and $1 \% \mathrm{SA}$ are about $18.9-22.5-11.5$ and $26.3 \times 10^{3} \mathrm{mS} / \mathrm{cm}$ in the first $40 \mathrm{~min}$ of hydration and these specimens solidified. Solidification of specimens with $1.5 \% \mathrm{SA}$ rapidly occurred. ST of specimens with $2 \% \mathrm{SA}$ is about $10 \mathrm{~min}$. The same condition is current for specimens with $0.50 \% \mathrm{SA}$. $\mathrm{ST}$ of this specimens increases a little and it reaches average to $30 \mathrm{~min}$. Due to rapid solidification of both specimens these have not workability and applicability for traditional concrete. The EC values of fresh specimens with $0.75 \% \mathrm{BA}$ and $1 \% \mathrm{SA}$ are about $17.8-19.8-11.8-16.1$ and $10.6 \times 10^{3} \mathrm{mS} / \mathrm{cm}$ in the first $180 \mathrm{~min}$ of hydration and these specimens solidified. Solidification of specimens with $1.5 \%$ SA occurred in 30-40 min. EC values of specimens with $2 \% \mathrm{SA}$ increased from $21.4 \times 10^{3}$ to $41.9 \times 10^{3} \mathrm{mS} / \mathrm{cm}$ during $90 \mathrm{~min}$ and regressed to $17.6 \times 10^{3} \mathrm{mS} / \mathrm{cm}$ in next $60 \mathrm{~min}$. FST of specimens with $2 \% \mathrm{SA}$ is approximately $150 \mathrm{~min}$. The same condition is current for specimens with $\mathrm{SA}$ and $1 \% \mathrm{BA}$. Especially, EC value of specimens with $2 \%$ SA reached to $52.7 \times 10^{3} \mathrm{mS} / \mathrm{cm}$ at the end of $150 \mathrm{~min}$ and FST of the specimen is about 180 min (Fig. 11).

- When EC values of specimens with $\mathrm{CC}$ and without BA was analyzed, it reached to $56.5 \times$ $10^{3} \mathrm{mS} / \mathrm{cm}$ at the end of $300 \mathrm{~min}$ for $1 \% \mathrm{CC}$, $55.6 \times 10^{3} \mathrm{mS} / \mathrm{cm}$ at the end of $240 \mathrm{~min}$ for $1.5 \% \mathrm{CC}$ and $52.7 \times 10^{3} \mathrm{mS} / \mathrm{cm}$ at the end of $270 \mathrm{~min}$ for $2 \% \mathrm{CC}$. EC values of specimens with $0.25 \% \mathrm{BA}$ also reached to $37 \times 10^{3} \mathrm{mS} / \mathrm{cm}$ at the end of $330 \mathrm{~min}$ for $1 \% \mathrm{CC}, 37.3 \times 10^{3} \mathrm{mS} / \mathrm{cm}$ at the end of $180 \mathrm{~min}$ for $1.5 \% \mathrm{CC}, 30 \times 10^{3} \mathrm{mS} / \mathrm{cm}$ at the end of $150 \mathrm{~min}$ for $2 \% \mathrm{CC}$ and $83.7 \times 10^{3} \mathrm{mS} / \mathrm{cm}$ at the end of $330 \mathrm{~min}$ for $2 \% \mathrm{CC}$. The EC values of specimens with $0.50 \% \mathrm{BA}$ are close to those of control specimens (PC). While BA ratio of specimens was increasing, EC values quickly decreased (Fig. 12). 


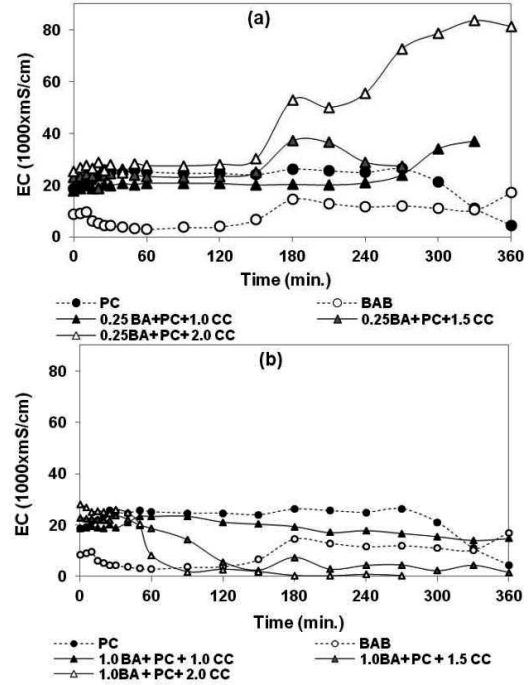

Fig. 12. Time-dependent EC changes of $0.25 \%$ (a) and $1.0 \%$ (b) ratios of $\mathrm{BA}$, different ratios of $\mathrm{CC}$ included $\mathrm{PC}$ and control mortar mixtures.

\section{Conclusion}

This study is aimed at obtaining of the mortar mixture designs having the highest possible $\mathrm{B}_{2} \mathrm{O}_{3} / c$ ratio and the closest penetrability and hydration properties to control mortar mixtures. So setting retardation and strength problems will be resolved and the expected technological benefit can be obtained.

In the study four different $\mathrm{B}_{2} \mathrm{O}_{3} / c$ ratios $(0.07,0.15$, 0.22 , and 0.30$)$ are used. Two different chemical substances are tested as stabilizers in order to suppress the effect of setting retardation of BA. At first, IST and FST are calculated. IST and FST of control mortar mixtures are 162-255 min for PC, 218-292 min for BAB and 353407 min for CAC. The IST and FST of CAC specimens including $\mathrm{BA}$ increased 2-4 times. In stabilizer-free PC specimens for the rate of $\mathrm{B}_{2} \mathrm{O}_{3} / c=0.3$, IST increased twice and the FST increased 3 times. In mortar mixtures including stabilizers for the rate of $\mathrm{B}_{2} \mathrm{O}_{3} / c=0.3$, IST and FST of mortar mixtures with $\mathrm{CC}$ are $40 \mathrm{~min}$ and 80 min, respectively. IST and FST of mortar mixtures with SA are about 140-240 min. In CAC specimens because of anion and cation insufficiency in the environment, the formation of $\mathrm{CBH}_{6}$, precipitation onto cement particles and dissolve again circulation occur in a long process. So compared to the STs of PC, BCs is much more in retard than the STs of CAC.

$T$ is an indicator of hydration speed. In $6 \mathrm{~h}$ periods, $T$ reached to $46^{\circ} \mathrm{C}$ in $\mathrm{PC}$ specimen and $40^{\circ} \mathrm{C}$ in BAB specimens according to time-dependent $T$ data. For $\mathrm{B}_{2} \mathrm{O}_{3} / c=0.3$ ratio, the $T$ values is about $27^{\circ} \mathrm{C}$ in specimen with $\mathrm{CC}$ and between 33 and $40^{\circ} \mathrm{C}$ in specimens with SA.

Higher or lower $\mathrm{pH}$ values can be related to the reaction of cement particles with pore water or the deceleration of the hydration reaction. $\mathrm{pH}$ value of control PC specimens is about 13 after contact with water, in during substantially whole of the $6 \mathrm{~h}$ period it continued in the same manner. Initially, while $\mathrm{pH}$ value of $\mathrm{BAB}$ specimen was 13 , it decreased gradually and it regressed to 11 at $4 \mathrm{~h}$ and then again it reached to 12.8 . This situation is related to $\mathrm{CBH}_{6}$ formation. For the ratio of $\mathrm{B}_{2} \mathrm{O}_{3} / c=0.3$, $\mathrm{pH}$ value of specimen with $\mathrm{SA}$ only reached to 13 among the specimens used stabilizer.

EC value is also important in terms of showing the total ion content in porous water and thus the solubility of cementitious compounds. The EC value of control PC specimen is $26000 \mathrm{mS} / \mathrm{cm}$ between 4 to $5 \mathrm{~h}$. In BAB specimens it was $9000 \mathrm{mS} / \mathrm{cm}$ at first and then regressed to a value of $3000 \mathrm{mS} / \mathrm{cm}$, increased $12000 \mathrm{mS} / \mathrm{cm}$ in $4-5 \mathrm{~h}$ period and reached $17000 \mathrm{mS} / \mathrm{cm}$ in the end of $6 \mathrm{~h}$ period. For the $\mathrm{B}_{2} \mathrm{O}_{3} / c=0.3$ ratio, while $\mathrm{EC}$ value of specimen with SA reached to $52000 \mathrm{mS} / \mathrm{cm}$ in the end of $150 \mathrm{~min}$, the EC value of specimen with $\mathrm{CC}$ was $28000 \mathrm{mS} / \mathrm{cm}$ at the first, then it rapidly regressed to $2000 \mathrm{mS} / \mathrm{cm}$ in the end of $90 \mathrm{~min}$.

As a result, for the highest $\mathrm{B}_{2} \mathrm{O}_{3} / c$ ratio $(0.3)$ chosen in this study, the closest properties to the workability and other properties of control-PC specimens was provided by SA accelerator considering the IST and FST, $T, \mathrm{pH}$, and $\mathrm{EC}$ values.

\section{Acknowledgments}

This study was supported by the Suleyman Demirel University Scientific Research Project Coordination Unit (Project No. 2573M10).

\section{References}

[1] S. Bell, P.V. Coveney, Molecular Simulation, Informa, UK 1998, p. 331.

[2] I. Kula, A. Olgun, V. Sevinc, Y. Erdogan, Cem. Concr. Res. 32, 227 (2002).

[3] Ş. Targan, A. Olgun, Y. Erdoğan, V. Sevinç, Cem. Concr. Res. 33, 1175 (2003).

[4] A. Sağlık, O. Sümer, E. Tunç, M.F. Kocabeyler, R.S. Çelik, DSI technical bulletin, Vol. 105, Ankara 2009.

[5] D.E. Volkman, P.L. Bussolini, JTE 20, (1992).

[6] D. Demir, G. Keleş, Nucl. Instrum. Methods Phys. Res. B 245, 501 (2006).

[7] BOREN, "Bor ve çimento", http://www.eie.gov.tr/ duyurular/EV/EV_etkinlik/2008_bildiriler/04OTURUM_ve_AR-GE/0403.pdf.

[8] H.F.W. Taylor, Cement Chemistry, 2nd ed., Thomas Telford Pub., London 1997.

[9] J.R. Conner, Chemical Fixation and Solidification of Hazardous Wastes, Van Nostrand Reinhold, New York 1990.

[10] J. Jeffrey, L. Garner, W. House, Waste Manag. 2, 359 (1991).

[11] Analyses Results of Monthly (November) BAB Cement in GOLTAS Cement Co. Operation, Isparta 2007.

[12] Analyses Results of Monthly Cement in GOLTAS Cement Co. Operation, Isparta 2009.

[13] TS EN 196-3, Methods of testing cement-part 3: Determination of setting time and soundness, Turkish Standard Institute TSE, Ankara 2003. 